\title{
In Situ Morphology of Nitrifying-Like Bacteria in Aquaculture Systems
}

PAUL W. JOHNSON* AND JOHN MCN. SIEBURTH

Narragansett Marine Laboratory, Graduate School of Oceanography, University of Rhode Island, Kingston, Rhode Island 02881

Received for publication 4 August 1975

\begin{abstract}
The in situ microbiota from several aquaculture facilities with active nitrification was examined by transmission electron microscopy of thin sections for the presence of bacteria that contained intracytoplasmic membranes characteristic of the nitrifying bacteria. Colonies of bacteria with the cellular morphology of a species of Nitrosomonas were found to be present in both the culture water and in the biological filter slime of a freshwater chinook salmon (Oncorhynchus tshawytscha) culture system. Bacteria in the water possessed the normal nitrosomonas type of ultrastructure, whereas similar bacteria in the slime had an aberrant morphology due to multiple invaginations of the cell wall and cytomembranes and a significantly greater number of ribosomes. These nitrosomonas-like bacteria lysed during enrichment in commonly used media. Bacteria with the morphology of species of Nitrosomonas and Nitrosococcus were also observed in colonies in the surface slimes of marine culture systems for striped bass (Morone saxatilis) and quahaug (Mercenaria mercenaria).
\end{abstract}

Closed-system aquaculture has become an important technology in the production of food from aquatic animals. Ammonia and nitrite, which rapidly accumulate in the water, are usually maintained at nontoxic levels by nitrification in biological filters $(6,8,15)$. The chemolithotrophic bacteria responsible for nitrification are presently classified by their cellular morphology in pure culture and by the oxidation of either ammonia or nitrite (18). Ultrastructural studies have shown that the predominant ammonia oxidizer, Nitrosomonas europaea, is a rod-shaped bacterium with intracytoplasmic membranes about the periphery of the cell (18), whereas the most common nitriteoxidizing bacterium, Nitrobacter winograd$s k y i$, is a pear-shaped cell with a cap of intracytoplasmic membranes located at one end (18). Direct observation of the nitrifying bacteria in natural environments, however, has been limited to studies involving light microscopy with immunofluorescent techniques $(4,5)$.

The electron microscopic observation of nitrifying bacteria in situ would be helpful under certain conditions in determining their relative abundance, nature, and diversity. Such studies would be difficult in natural microcosms with low levels of nitrification and with the presence of sunlight and anaerobic conditions conducive to the enrichment of other bacteria with a similar ultrastructure. However, in ammonia-enriched aquaculture facilities with extremely ac- tive nitrification occurring under highly oxidizing but poor light conditions, the occurrence of morphologically similar forms in numbers that could be easily detected by electron microscopy is very unlikely. Furthermore, the cystlike colonies of the nitrifiers are unique and are not found with the methane-oxidizing bacteria of the same ultrastructure $(3,14,20)$, whereas the thick cell wall of the cyanobacteria (1) and the distinctive cell morphologies of the purple sulfur and purple nonsulfur bacteria $(2,9,10)$ would distinguish them. In this paper we report our observations on the in situ occurrence of bacteria with the morphology of nitrifying bacteria in several aquaculture facilities with active nitrification.

(This investigation was reported in part at the 75th Annual Meeting of the American Society for Microbiology, New York, N. Y., 27 April-2 May, 1975.)

\section{MATERIALS AND METHODS}

Aquaculture systems. The majority of samples were taken from an active, closed-culture system (8) for chinook salmon (Oncorhynchus tshawytscha) at the University of Rhode Island, Kingston. This culture system consisted of two large, fiberglass, silolike tanks, with the water from them recirculating through two rectangular biological filters containing submerged, corrugated polyvinyl-chloride modules as a substrate. Approximately 1,000 young salmon $(0.5 \mathrm{~kg}$ each) were being reared in fresh water $(\mathrm{pH} 7.0$ ) at $14 \mathrm{C}$ in a total volume of 15,000 
liters. The fish were fed $5 \mathrm{~kg}$ of food pellets each day and produced about $150 \mathrm{~g}$ of $\mathrm{NH}_{3}-\mathrm{N}$ per day or 10 mg of $\mathrm{NH}_{3}-\mathrm{N}$ per liter per day. The system was usually run $95 \%$ closed, with no more than $5 \%$ new water added each day. Inorganic nitrogen levels remained constant at 0.5 to $0.7 \mathrm{mg}$ of $\mathrm{NH}_{3}-\mathrm{N}$ per liter, 0.2 to $0.4 \mathrm{mg}$ of $\mathrm{NO}_{2}-\mathrm{N}$ per liter, and 50 to 60 $\mathrm{mg}$ of $\mathrm{NO}_{3}-\mathrm{N}$ per liter. The biological filters were continually aerated and the culture tanks were sparged with oxygen, so that the water in the entire system was saturated with respect to oxygen.

The second system examined was a small aquarium containing approximately 25 young striped bass (Morone saxatilis), located at the University of Rhode Island Marine Experiment Station, Jerusalem. The fish were being cultured in 75 liters of $30 \%$ sea water ( $\mathrm{pH} \mathrm{7.5)}$ at ambient temperature, which was recirculated through a bed of glass wool and charcoal by an airlift pump. Ground shrimp was fed to the fish each day, and ammonia levels in the water averaged 5 to $10 \mathrm{mg}$ of $\mathrm{NH}_{3}-\mathrm{N}$ per liter at the time of sampling. Nitrite and nitrate were not measured.

The remaining samples were taken from a semiclosed culture system for the quahaug (Mercenaria mercenaria) at the Aquacultural Research Corp., Dennis, Mass. Small adult clams were raised in shallow trays and on racks submerged in three 2,500 -liter tanks in a total volume of 11,000 liters of $28 \%$ seawater ( $\mathrm{pH} 7.5)$ at $22 \mathrm{C}$. The seawater in this system was replaced four times daily with water from an adjacent bay. Airlifts were used in the three tanks for circulation, and a small submerged gravel filter was used while recirculating the water to remove large particulate matter. Microalgae from an algal pond were fed to the clams, and ammonia levels in the culture water normally averaged 0.3 to $0.5 \mathrm{mg}$ of $\mathrm{NH}_{3}-\mathrm{N}$ per liter. Nitrite and nitrate were not measured.

Enrichment cultures. Both filter slime and culture water from the chinook salmon culture system were used as inocula for enrichments for nitrifying bacteria. Approximately $1.0 \mathrm{~g}$ of slime or $1.0 \mathrm{ml}$ of water was added to $100 \mathrm{ml}$ of a sterile mineral salts medium (19) in 250-ml Erlenmeyer flasks. The flasks containing ammonium or nitrite as substrate were placed in a G24 environmental incubator shaker (New Brunswick Scientific Co., Inc., New Brunswick, N.J.) at 15 and $25 \mathrm{C}$ and shaken at 250 rpm. Nitrate or nitrite formation was observed in the enrichment media either by spot test or by drop in $\mathrm{pH}$ of the ammonium medium as indicated by phenol red (11). The $\mathrm{pH}$ in the ammonium-oxidizing cultures was maintained near $\mathrm{pH} 7.5$ by the addition of sterile $3 \% \mathrm{Na}_{2} \mathrm{CO}_{3}$ during the course of incubation. After months of incubation and repeated transfers, the cultures were examined for nitrifying-like bacteria by electron microscopy of thin sections.

The effect of the high level of substrate of this enrichment medium on the bacteria observed in situ was examined in the following experiment. Approximately $10 \mathrm{~g}$ (wet weight) of filter slime of the salmon system was scraped from the polyvinylchloride substrate and placed in $100 \mathrm{ml}$ of filtersterilized $(0.22 \mu \mathrm{m})$ culture water. One milliliter of this slurry was inoculated into $100 \mathrm{ml}$ of filtersterilized culture water in 250-ml Erlenmeyer flasks. Control flasks received $1 \times$ ammonium (in situ concentration, $0.05 \mathrm{mg}$ of $\mathrm{NH}_{4}{ }^{+} / 100 \mathrm{ml}$ ) twice daily, whereas experimental flasks received $500 \times$ ammonium or nitrite $\left(25 \mathrm{mg}\right.$ of $\mathrm{NH}_{4}^{+} / 100 \mathrm{ml}$ and 10 $\mathrm{mg}$ of $\mathrm{NO}_{2}^{-} / 100 \mathrm{ml}$, respectively) at the beginning of the experiment. All flasks were incubated on a shaker at $15 \mathrm{C}$ for 3 to 7 days. Cell pellets of these cultures were examined by transmission electron microscopy (TEM) for the condition and appearance of the in situ nitrifying-like bacteria.

Collection of samples. To examine the slime of the biological filter of the salmon system by both scanning electron microscopy (SEM) and TEM of identical samples, polycarbonate membrane filters (Nuclepore Corp., Pleasanton, Calif.) were used as an inert substrate for the attachment of the microbial flora. For TEM, strips measuring 1.0 by $4.5 \mathrm{~cm}$ were cut from the membrane filters (47-mm diameter; $0.4-\mu \mathrm{m}$ pore size) and were mounted rough side exposed, using a warmed spatula to adhere it to 1mm-thick strips of polypropylene with dimensions of 1.2 by $7.0 \mathrm{~cm}$. These strips were then exposed by securing them $0.5 \mathrm{~m}$ deep in the biological filter. The microbial slime was allowed to accumulate on the surface of the membrane filter, and the samples were removed after 20 to 40 days of incubation directly into buffered fixative. The membrane filter strips with adhering slime were carefully "peeled" off the polypropylene support and prepared for thin sectioning. By making cross-sections through the membrane filter and its attached microbial flora, the number and distribution of nitrifying-like bacteria could be observed. For SEM examination, the membrane filter plus support was cut into $1.0-\mathrm{cm}$ squares after fixation and remained intact throughout the preparation procedure and observation.

The slimes of the marine systems were sampled by scraping the existing film from the surface of the substrate into tubes of buffered fixative. The culture waters of all systems were sampled by collecting 250-ml aliquots and fixing each with either $0.3 \%$ (salmon system) or $3 \%$ (marine systems) glutaraldehyde (vol/vol). The enrichment cultures were fixed by the addition of glutaraldehyde to each flask at $3 \%$ (vol/vol). The suspended slime scrapings, culture waters, and enrichment cultures were centrifuged at $5,900 \times g$ for $30 \mathrm{~min}$, and the pellets were prepared for thin sectioning as described below.

TEM. The exposed strips were initially fixed in tubes containing $3 \%$ glutaraldehyde in $0.1 \mathrm{M}$ sodium cacodylate buffer ( $\mathrm{pH} 7.2$ ) at $4 \mathrm{C}$ for 24 to $72 \mathrm{~h}$. After three 15-min rinses in fresh buffer, the filter strips from the salmon system were carefully removed from their support and cut into $1-\mathrm{mm}^{2}$ pieces on a glass microscope slide with a razor blade. These small squares with attached microbial slime were then embedded in $1.5 \%$ sterile purified agar (Difco) at $46 \mathrm{C}$. The hardened agar was cut into 1 to $2-\mathrm{mm}$ cubes around each piece of filter, and these cubes were placed in $0.1 \mathrm{M}$ cacodylate buffer in vials. The cell pellets from the salmon culture water and the enrichment cultures were also embedded in agar and cut into $1-\mathrm{mm}$ cubes, but were fixed again in $3 \%$ 
glutaraldehyde in the same buffer for $2 \mathrm{~h}$ at room temperature. After three 15-min changes of buffer, the culture water, enrichment culture, and biological filter samples were fixed for $2 \mathrm{~h}$ in $1 \%$ osmium tetroxide in $0.1 \mathrm{M}$ cacodylate buffer at room temperature. The biological filter slimes of the marine systems were fixed in $3 \%$ glutaraldehyde in $0.2 \mathrm{M}$ sodium cacodylate buffer ( $\mathrm{pH} 7.2)$ with $3 \%$ sucrose, and the marine culture waters were fixed with $3 \%$ glutaraldehyde (vol/vol) overnight at $4 \mathrm{C}$. Both were then centrifuged, the pellets were embedded in agar, and 1-mm agar cubes were cut from each. These cubes were washed once with $0.2 \mathrm{M}$ cacodylate buffer with sucrose for $15 \mathrm{~min}$, followed by two changes of buffer minus sucrose for $15 \mathrm{~min}$ each. The marine samples were then fixed in $1 \%$ osmium tetroxide in $0.2 \mathrm{M}$ cacodylate buffer for $2 \mathrm{~h}$ at room temperature. All samples were dehydrated in a graded ethanol series to absolute, and were infiltrated and embedded in Spurr's epoxy resin (16). The blocks were sectioned with a DuPont diamond knife (DuPont Instruments, Wilmington, Del.) on a Sorvall MT2-B ultramicrotome (DuPont/Sorvall, Newtown, Conn.). After staining with uranyl acetate and lead citrate, the thin sections were examined and photographed with a Zeiss EM9S-2 transmission electron microscope.

\section{RESULTS}

A dense flocculent growth of microorganisms, 1 to $5 \mathrm{~mm}$ thick, was visible on the surface of the exposed strips upon their removal from the biological filter of the salmon system to tubes of fixative. Examination of this slime by light microscopy and by SEM and TEM showed that it was composed of an extremely dense and diverse population of bacteria, naked and scale-bearing amoebae, attached testaceae, ciliated protozoa, and fungi.

Only one morphologically distinct type of bacterium with intracytoplasmic membranes was observed by TEM in the slime of the extremely active nitrifying filter of this system. Because of its ultrastructural characteristics of peripherally located cytomembranes in generally oval- to rod-shaped cells, the bacterium closely resembled a species of Nitrosomonas. No other bacteria contained intracytoplasmic membranes suggestive of other species of nitrifiers. The nitrosomonas-like bacteria were present both as single cells and in aggregations of dividing cells or colonies (Fig. 1 and 2). The dominant colonial form was the compact cyst type of aggregate (Fig. 2 and 3), although the loosely embedded zoogloeal type of colony (17, 23) was also observed (Fig. 4). During light microscopy of thick sections stained with azureII and toluidine blue, the cyst-type colonies could be easily recognized by the intense blue staining of the polysaccharide-like material surrounding the cells. Both types of colonies accounted for approximately $5 \%$ of the bacterial biomass present. Within the cyst type of colony, the bacteria were embedded within a dense polysaccharide-like matrix (Fig. 2 and 3). These colonies contained from 3 to 180 cells in crosssection and measured from 1.0 by $2.0 \mu \mathrm{m}$ to 8.5 by $16.0 \mu \mathrm{m}$, respectively. The oval- to rodshaped cells were approximately 0.5 to $0.7 \mu \mathrm{m}$ in width and 0.7 to $1.2 \mu \mathrm{m}$ in length. Dividing cells of the nitrosomonas-like species were present at the center as well as at the edge of the colonies (Fig. 2).

All colonies and single cells of the nitrosomonas-like form in this slime layer exhibited a very irregular cellular morphology (Fig. 2-5) in contrast to the uniform rod shape found in pure cultures (19). This aberrant form was characterized by multiple invaginations of both the cell wall and cytomembranes (Fig. 5). Also present in these cells was a dense layer of ribosomes concentrated primarily at the edge of the membrane system. The multilayered cell wall was found to be composed of dark and light outer layers, with a faint inner peptidoglycan layer occasionally visible. The individual membranes of the peripheral lamellae were situated very close to one another, usually forming a bilayer of adjacent membranes (Fig. 5).

The culture water of the same system also contained cyst-type colonies of a similar nitrosomonas-like form, but one with the normal morphology of bacteria in pure culture (19). The largest colonies contained from 30 to $\mathbf{4 0}$ short

Figures 1-5. Electron micrographs of the microbial flora of the biological filter of the chinook salmon culture system. (Fig. 1) Cross-section of part of the slime adhering to a Nuclepore membrane filter (Nf) after being exposed for 23 days. A colony (c) of nitrosomonas-like bacteria (enlarged in Fig. 2) as well as several other bacteria is suspended in the slime. An empty lorica of a testacean $(t)$ is attached to the membrane filter, while a ciliate (ci) is nearby. Bar equals $10 \mu \mathrm{m}$. (Fig. 2) Irregularly shaped nitrosomonas-like cells within a typical cyst-type colony of about 60 cells in cross-section are embedded in a polysaccharide-like matrix (ps). Bar equals $1 \mathrm{~mm}$. (Fig. 3) A smaller colony of the same type is attached to the membrane filter surface. Peripheral cytomembranes are visible with invaginations of the lamellae and cell wall. Bar equals $1 \mu m$. (Fig. 4) A colony of the zoogloeal type contains similar nitrosomonas-like cells in loose aggregation within no visible matrix. Bar equals $1 \mathrm{~mm}$. (Fig. 5) A single cell from a cyst-type colony shows general characteristics of the nitrifying-like bacteria in this slime: outer layers of the cell wall (ol), bilayers of peripheral cytomembranes (cm), invaginations ( $i$ ) of wall and cytomembranes, and a dense complement of ribosomes ( $r$ ) in the cytoplasm. Bar equals 0.1 $\mu \mathrm{m}$. 


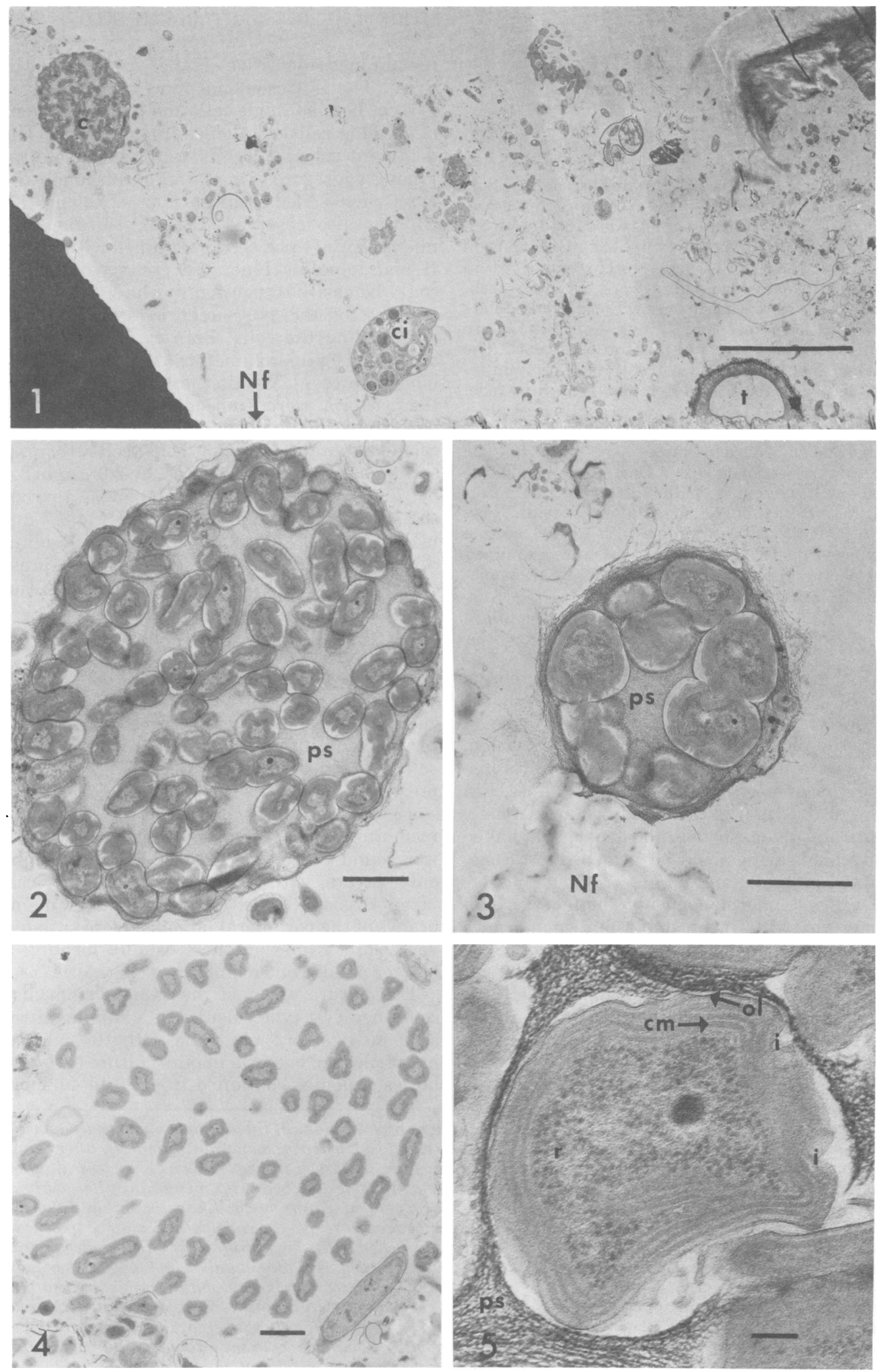


rod- to oval-shaped cells in cross-section, 0.5 to 0.8 by $1.0 \mu \mathrm{m}$, embedded in a polysaccharidelike matrix (Fig. 6). Smaller colonies were found to be numerous (Fig. 7 and 8). Individual cells from the culture water (Fig. 9) exhibited the characteristic nitrosomonas-type ultrastructure of ellipsoidal or short rods with peripheral cytomembranes (19). In contrast to the nitrosomonas-like cells found in the filter slime, those from the culture water had a very regular wall and distinct membrane formation and also possessed fewer ribosomes, primarily adjacent to the lamellae (Fig. 10). However, the structure of the cell wall and the number of cytomembrane layers appeared to be similar in the cells from both sources (Fig. 5 and 9).

The striped bass aquarium also contained bacteria with the cellular morphology of a species of Nitrosomonas. Zoogloeal-type colonies of this bacterium were present in the slime on the walls of the tank (Fig. 11) and in the filter bed of glass wool (Fig. 12). The cells in these colonies were rod shaped in longitudinal section, approximately $0.7 \mu \mathrm{m}$ wide by 1 to $2 \mu \mathrm{m}$ long, and were not embedded in any visible matrix. High magnification of the cell wall (Fig. 13) showed that these cells possessed the extra cell wall layer usually found on marine Nitrosomonas species (17). In contrast to the salmon system, these bacteria were not observed in the culture water.

The quahaug culture system showed the greatest diversity of bacteria with intracytoplasmic membranes. Three to four morphological types of bacteria with different arrangements of the cytomembranes were present in the slime. In greatest numbers were colonies of bacteria with the morphology of a species of Nitrosococcus (S. W. Watson, personal communication) in both the cyst type (Fig. 14) and the zoogloeal type of aggregation (Fig. 15). These colonies contained cells, 0.5 by $1.0 \mu \mathrm{m}$, that had up to seven or more bilayers of membranes arranged on one side of each cell and were usually embedded in a polysaccharide-like matrix (Fig. 16). Also present were zoogloeal-type colonies of a nitrosomonas-like bacterium with peripheral cytomembranes (Fig. 17), but lacking the extra cell wall layer common to marine species (17) (see Fig. 13). These cells, 0.7 by 1.25 $\mu \mathrm{m}$, were not contained within a polysaccharide-like matrix.

All ammonium enrichments inoculated from the salmon culture system showed positive ammonia oxidation. Pellets of these nitrifying cultures examined after months of repeated transfer and incubation failed to show bacteria with the morphology of a Nitrosomonas species. Nitrite enrichments inoculated from the same sources and from ammonium enrichments became turbid and produced nitrate. Pellets of these cultures contained cells with the characteristic morphology of a Nitrobacter species. It is paradoxical that nitrobacter-like cells were never observed in the natural populations.

The contradictory cultural results above prompted an experiment to observe the conditions of natural populations of cells during enrichment in the same media. After 3 to 7 days in either ammonium or nitrite, most cells were undergoing lysis and falling apart (Fig. 18).

\section{DISCUSSION}

The early research of Winogradsky (21-23) placed the gram-negative chemolithotrophic nitrifying bacteria into two physiological groups: the ammonia oxidizers and the nitrite oxidizers. Since then, ecological studies on the process of nitrification have been primarily indirect observations on rates of ammonia removal and of nitrite and nitrate production (13). The in situ nitrifiers are usually enumerated by indirect cultural procedures using most-probable-number techniques (7). Direct examination of nitrifying bacteria from natural environments has been limited to the use of immunofluorescence microscopy $(4,5)$.

Using TEM, our most comprehensive examination of nitrifying-like bacteria in situ was accomplished in the freshwater salmon system. We have observed that nitrosomonas-like forms were present in aggregations of cells or colonies in the culture water (Fig. 6-10) as well as in the biological filter (Fig. 1-5). Although these bacteria possessed the same cell wall and characteristic peripheral cytomembranes in both environments, they exhibited gross differences in

Figures 6-10. Electron micrographs of the nitrosomonas-like bacteria in the culture water of the chinook salmon culture system. (Fig. 6) A cyst-type colony of about 30 cells in cross-section. The oval-shaped cells with peripheral cytomembranes are embedded in a polysaccharide-like matrix (ps). Bar equals 1 mm. (Fig. 7) Smaller colonies were found to be more numerous, possibly due to the washout rate of the system. Bar equals 1 $\mu \mathrm{m}$. (Fig. 8) A representative colony of this nitrifying-like bacterium in the water possesses cells with a normal morphology. Bar equals $1 \mathrm{\mu m}$. (Fig. 9) This oval-shaped cell from the water is characterized by a regular arrangement of peripheral cytomembranes and cell wall. Fewer ribosomes $(r)$ are present and are concentrated at the edge of the cytomembranes. Bar equals $0.1 \mu \mathrm{m}$. (Fig. 10) Higher magnification of the outer layers (ol) of the cell wall and cytomembranes (cm) shows that they are more distinct and well ordered in these cells. Bar equals $0.1 \mu \mathrm{m}$. 

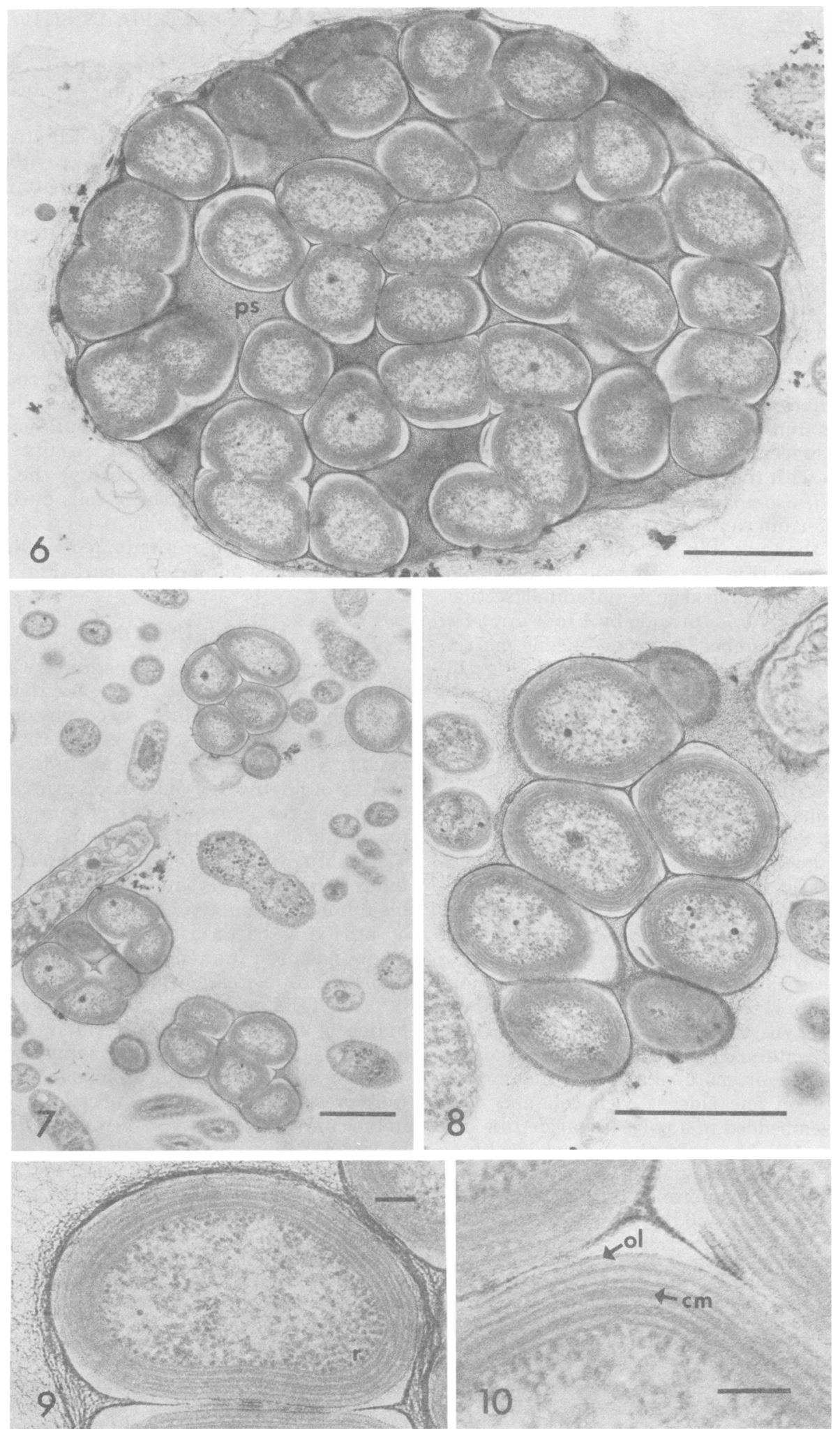

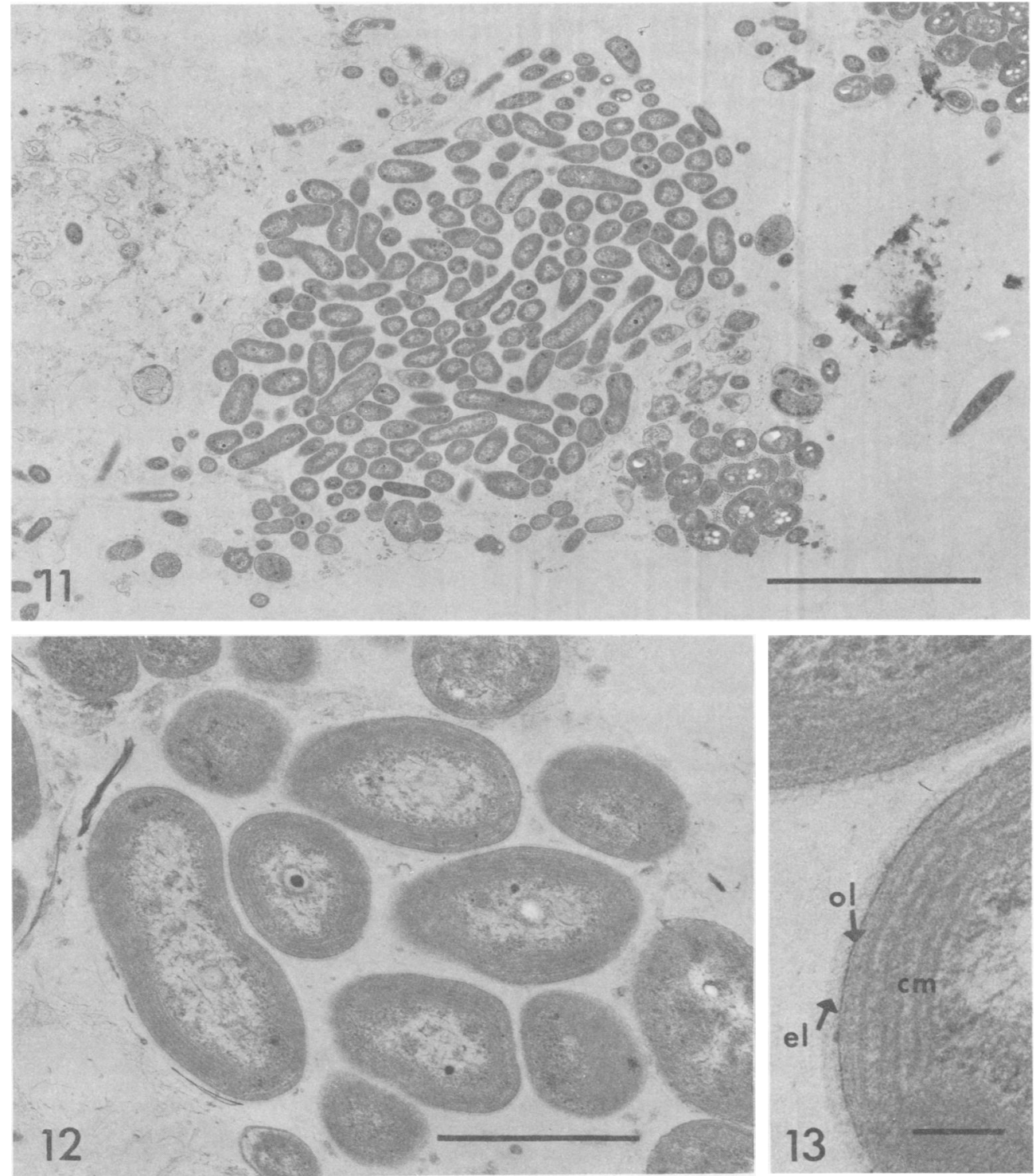

FIGUREs 11-13. Electron micrographs of the marine nitrifying-like bacteria from the striped bass aquarium. (Fig. 11) A zoogloeal-type colony of this bacterium from the slime on the wall of the tank. The cells are not embedded in any visible polysaccharide-like matrix. Bar equals $5 \mathrm{\mu m}$. (Fig. 12) This marine bacterium is typically rod shaped with peripheral cytomembranes, characteristic of a species of Nitrosomonas. Bar equals 1 $\mu m$. (Fig. 13) Higher magnification shows the cytomembranes (cm) and outer wall layers (ol), and also the extra cell wall layer (el) commonly found in most marine species of Nitrosomonas. Bar equals $0.1 \mu \mathrm{m}$.

morphology, depending upon where they were found. In the culture water, these bacteria had the normal appearance of a species of Nitrosomonas (Fig. 9), whereas in the slime of the biological filter the same type of bacteria showed a very irregular morphology characterized by multiple invaginations of the cell wall and cytomembranes and also by a dense complement of ribosomes (Fig. 5). In speculating upon a possi- ble relationship between the structure and function of these cellular components, the invaginations of the cytomembranes may indicate an increase in their surface area, and the greater number of ribosomes may indicate an increased production of protein, including the nitrifying enzymes. The presumed morphological and physiological changes of this aberrant form suggest that these bacteria could be adapt- 

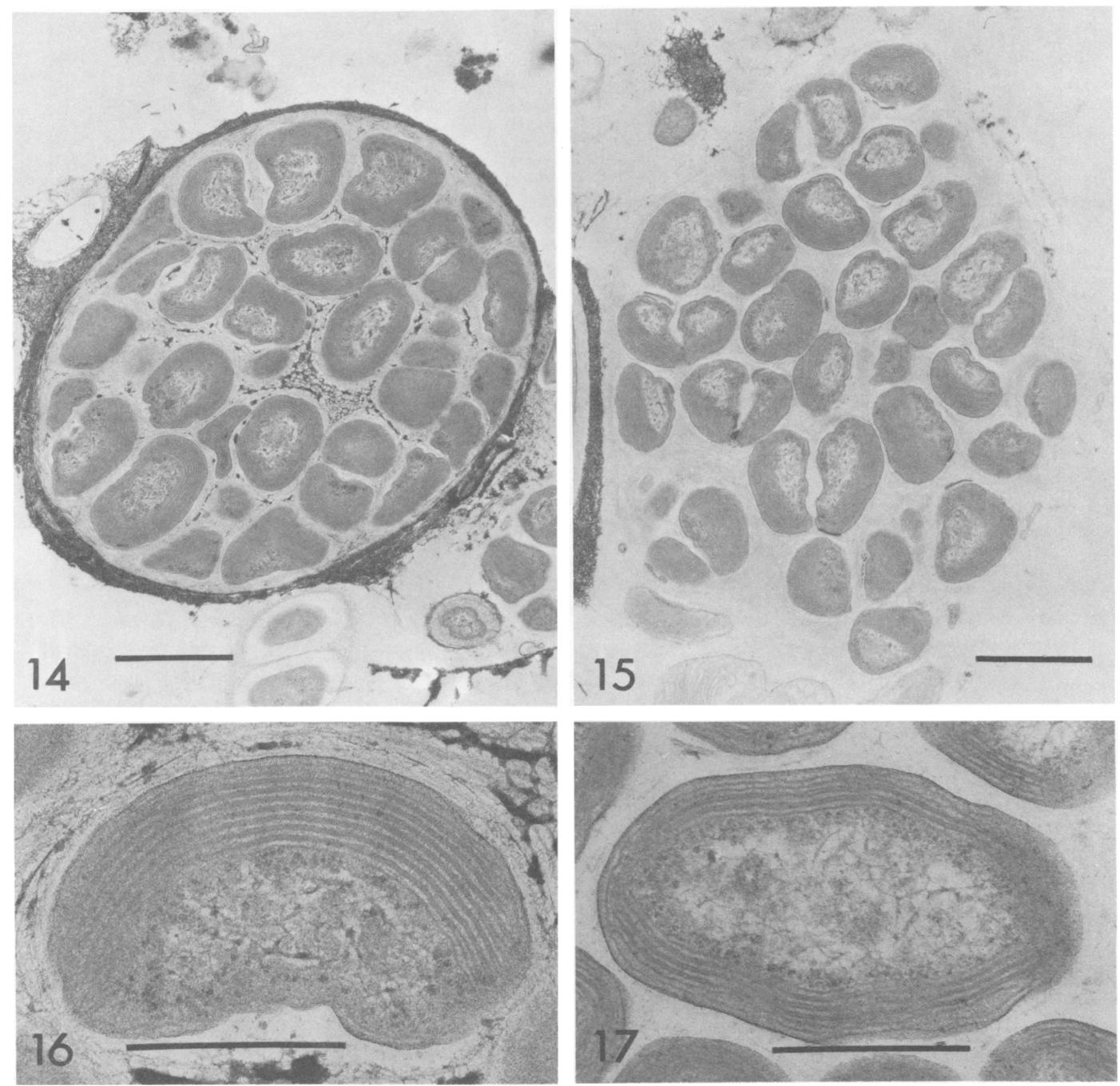

FIGURES 14-17. Electron micrographs of the marine nitrifying-like bacteria from the quahaung culture system. (Fig. 14) A cyst-type colony contains cells with the morphology of a species of Nitrosococcus within a polysaccharide-like matrix in compact aggregation. Bar equals $1 \mu \mathrm{m}$. (Fig. 15) Nitrosococcus-like bacteria were also present in zoogloeal-type colonies in which the cells were contained within a less dense material. Bar equals $1 \mathrm{\mu m}$. (Fig. 16) A bean-shaped cell from a nitrosococcus-like colony possesses seven bilayers of cytomembranes. Bar equals $0.5 \mu \mathrm{m}$. (Fig. 17) An oval cell with peripheral cytomembranes suggestive of a species of Nitrosomonas was also present in colonies in this system. Bar equals $0.5 \mu \mathrm{m}$.

ing to microzonal conditions that may be present in this filter slime. Competition for ammonia with the heterotrophic bacterial population is one possibility. All of the bacteria with an ultrastructure suggestive of nitrifiers that we observed in situ occurred mainly in cyst-like colonies. This is also the primary growth form in pure culture (S. W. Watson, personal communication).

The failure to enrich for the nitrosomonaslike bacteria in the salmon system was frustrat- ing. The observation that these bacteria lysed in the usual levels of ammonium in enrichment media explained why. It further indicated a possible sensitivity of these bacteria to cultural conditions, already indicated by the aberrant morphology of the cells observed in the filter slime. The absence of bacteria with the ultrastructure of the nitrite oxidizer $N$. winograd$s k y i$ in a culture system that was actively producing nitrate was unexpected. However, nitrite oxidizers that occur in colonies but lack 


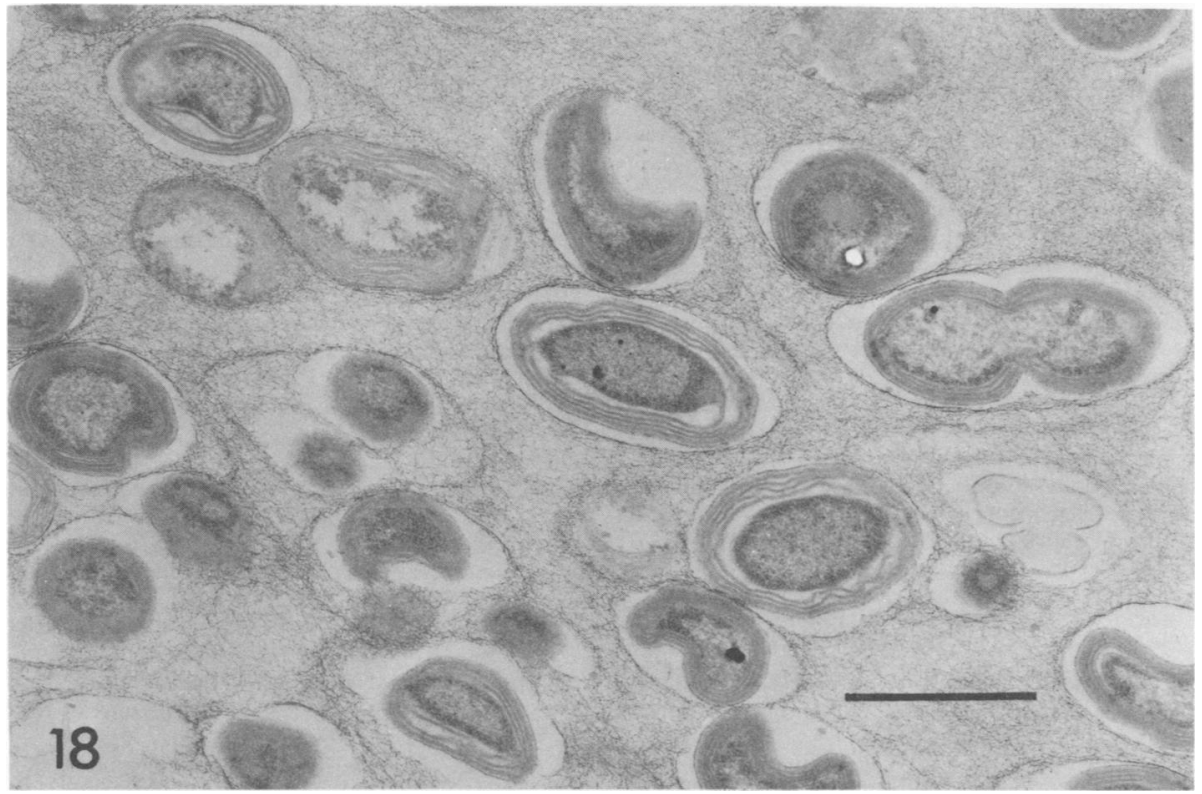

Figure 18. Electron micrograph of the nitrosomonas-like bacteria from the biological filter of the chinook salmon culture system. After 7 days enrichment in a conventional medium, the cells show marked lysis. Bar equals $1 \mu \mathrm{m}$.

the distinctive cytomembranes are known to exist (S. W. Watson, personal communication). Colonies of this bacterial form were quite common in this system. The failure to enrich for this type of bacterium, but the successful enrichment of a species of Nitrobacter, is an indication that standard cultural procedures may be missing ecologically important nitrifiers that cannot tolerate enrichment procedures.

All of our present knowledge of the ultrastructure of nitrifying bacteria is the result of work performed with pure cultures isolated with media identical to those we used (19). The examination of pure cultures of nitrifying and other bacteria with non-ecological levels of substrate is used to determine morphological, genetic, and physiological characteristics. Species that are not important in the ecosystem may be selected for, whereas species that are most active in the environment may be selected against by using common enrichment and most-probable-number techniques. We feel that enrichment and culture by dialysis or diffusion techniques (12) at ecological levels of substrate in the laboratory or in situ (D. M. Lavoie and J. McN. Sieburth, Abstr. Annu. Meet. Am. Soc. Microbiol. 1975, N13, p. 186; D. M. Lavoie, M. S. thesis, Univ. of Rhode Island, Kingston, 1975) could be used to advantage for isolating ecologically important species of nitrifying bacteria and for determining their growth rates in nature.
The microbial flora of the marine facilities was examined less frequently than that of the salmon system since nitrification was not as closely followed. The striped bass system was essentially closed, but had a low density of animals that would support a correspondingly lower population of nitrifiers. The high-density quahaug system, with four water changes per day, was a semi-flow-through system that would support a nitrifying population only in the slime attached to surfaces. The slime from this system contained at least two or three morphological types of nitrifying-like bacteria. This observation was expected, since a large variety of nitrifying bacteria in the oceanic environment have already been described (17). Further work on the natural population of nitrifiers in inshore waters should be conducted with ecologically compatible procedures to see whether an even greater diversity exists.

In the salmon system, both the attached and the suspended populations play a role in nitrification. Optimum oxidation of ammonia and nitrite occurred when the system was greater than $95 \%$ closed (less than 5\% water replenishment per day). Nitrification at a significant but reduced rate occurred during washout of the suspended microbiota, presumably due to nitrifying bacteria in the slime. The rapid uptake of ammonia and the concurrent formation of nitrate that had to be removed by denitrification (W. L. Balderston, Ph.D. thesis, Univ. of Rhode 
Island, Kingston, 1974) is further proof that the salmon culture system contained an active population of nitrifying bacteria.

\section{ACKNOWLEDGMENTS}

This research was supported in part by Sea Grant 04-3158-3 from the National Oceanic and Atmospheric Administration, U.S. Department of Commerce, and by grants GA41501X and DES74-01537 from the Biological Oceanography Program of the National Science Foundation. The electron microscopes were provided by contract 14-12-856 (TEM) from the Environmental Protection Agency and by grant GA-28905 (SEM) from the National Science Foundation.

We gratefully acknowledge T. Meade (chinook salmon) and B. Rogers and D. Westin (striped bass), of the University of Rhode Island, and R. Seshadri (quahaug), of the Aquacultural Research Corp., for allowing us to sample at these facilities. We also thank P. E. Hargraves and S. W. Watson for their critical reading of the manuscript.

\section{LITERATURE CITED}

1. Carr, N. G., and B. A. Whitton (ed.). 1973. The biology of blue-green algae. University of California Press, Berkeley and Los Angeles.

2. Conti, S. F., and P. Hirsch. 1965. Biology of budding bacteria III. Fine structure of Rhodomicrobium and Hyphomicrobium spp. J. Bacteriol. 89:503-512.

3. Davies, S. L., and R. Whittenbury. 1970. Fine structure of methane and other hydrocarbon-utilizing bacteria. J. Gen. Microbiol. 61:227-232.

4. Fliermans, C. B., B. B. Bohlool, and E. L. Schmidt. 1974. Autecological study of the chemoautotroph $\mathrm{Ni}$ trobacter by immunofluorescence. Appl. Microbiol. 27:124-129.

5. Fliermans, C. B., and E. L. Schmidt. 1975. Autoradiography and immunofluorescence combined for autecological study of single cell activity with Nitrobacter as a model system. Appl. Microbiol. 30:676-684.

6. Johnson, P. W., and J. McN. Sieburth. 1974. Ammonia removal by selective ion exchange, a backup system for microbiological filters in closed-system aquaculture. Aquaculture 4:61-68.

7. Matulewich, V. A., P. F. Strom, and M. S. Finstein. 1975. Length of incubation for enumerating nitrifying bacteria present in various environments. Appl. Microbiol. 29:265-268.

8. Meade, T. L. 1974. The technology of closed system culture of salmonids. Marine Tech. Rep. 30, Marine Advisory Service, University of Rhode Island, Narragansett.

9. Pfennig. N. 1967. Photosynthetic bacteria. Annu. Rev. Microbiol. 21:285-324.

10. Pfennig, N., and H. G. Trüper. 1974. The phototrophic bacteria, p. 24-75. In R. E. Buchanan and N. E. Gibbons (ed.), Bergey's manual of determinative bacteriology, 8th ed. The Williams \& Wilkins Co., Baltimore, Md.

11. Schmidt, E. L., J. A. E. Molina, and C. Chiang. 1973. Isolation of chemoautotrophic nitrifiers from Moroccan soils. Bull. Ecol. Res. Commun. 17:166-167.

12. Schultz, J. S., and P. Gerhardt. 1969. Dialysis culture of microorganisms: design, theory, and results. Bacteriol. Rev. 33:1-47.

13. Schwert, D. P., and J. P. White. 1974. Method for in situ measurement of nitrification in a stream. Appl. Microbiol. 28:1082-1083.

14. Smith, U., and D. W. Ribbons. 1970. Fine structure of Methanomonas methanooxidans. Arch. Mikrobiol. 74:116-122.

15. Spotte, S. H. 1970. Fish and invertebrate culture. Wiley-Interscience, New York.

16. Spurr, A. R. 1969. A low-viscosity epoxy resin embedding medium for electron microscopy. J. Ultrastruct. Res. 26:31-43.

17. Watson, S. W. 1971. Taxonomic considerations of the family Nitrobacteraceae Buchanan. Int. J. Syst. Bacteriol. 21:254-270.

18. Watson, S. W. 1974. Nitrobacteraceae, p. 450-456. In R. E. Buchanan, and N. E. Gibbons (ed.), Bergey's manual of determinative bacteriology, 8th ed. The Williams \& Wilkins Co., Baltimore, Md.

19. Watson, S. W., and M. Mandel. 1971. Comparison of the morphology and deoxyribonucleic acid composition of 27 strains of nitrifying bacteria. J. Bacteriol. 107:563569.

20. Weaver, T. L., and P. R. Dugan. 1975. Ultrastructure of Methylosinus trichosporium as revealed by freeze etching. J. Bacteriol. 121:704-710.

21. Winogradsky, S. 1890. Recherches sur les organismes de la nitrification. Ann. Inst. Pasteur Paris 4:257275.

22. Winogradsky, S. 1891 . Recherches sur les organismes de la nitrification. Ann. Inst. Pasteur Paris 5:577616.

23. Winogradsky, S. 1892. Contributions à la morphologie des organismes de la nitrification. Arch. Sci. Biol. Leningrad 1:86-137. 